\title{
Prediction of oil content in the mesocarp of fruit from the macauba palm using spectrometry ${ }^{1}$
}

\author{
Predição do teor de óleo do mesocarpo nos frutos de macaúba usando espectrometria
}

\author{
Sofrimento Fenias Savanto Matsimbe ${ }^{2 *}$, Sergio Yoshimitsui Motoike ${ }^{3}$, Francisco Assis de Carvalho Pinto ${ }^{4}$, Helio \\ Garcia Leite $^{5}$ e Gustavo Eduardo Marcatti ${ }^{6}$
}

\begin{abstract}
In the present work a model was developed for the prediction of the oil content of the mesocarp of fruit from the macauba palm, using visible and near infrared spectrometry. Reference values were determined the by Soxhlet method. The model was calibrated using spectral data from the mesocarp of macauba fruit by partial least squares regression, considering nine latent variables. The results of the calibration series were consistent with those of the validation series, registering an The coefficient of determination between the reference method and the developed model, systematic error between the predicted values and the measured values and root mean square error, for calibration and validation with independent data, respectively, equal to 0.8223, -9.2-14 and 5.917 and 0.7760, 7.081 and -0.064 . VIS-NIR spectroscopy is a viable tool in the evaluation of genotypes in breeding programs for the macauba palm.
\end{abstract}

Key words: Acrocomia aculeata. Quantification of the oil. VIS-NIR model calibration.

\begin{abstract}
RESUMO - No presente trabalho, foi desenvolvido um modelo para a predição do teor de óleo do mesocarpo nos frutos de macaúba, usando a espectrometria do visível e infravermelho próximo. Os valores de referência foram determinados pelo método soxhlet. O modelo foi calibrado usando dados espectrais do mesocarpo dos frutos de macaúba pela regressão por mínimos quadrados parciais, considerando nove variáveis latentes. Os resultados da série da calibração foram consistentes com os da série da validação, registrando o coeficiente de determinação entre o método referencia e o modelo desenvolvido, erro sistemático entre os valores preditos e os valores mensurados e a raiz quadrada do erro médio quadrático entre o método referência e o modelo desenvolvido, de 0,8223, -9,2-14 e 5,917 e de 0,7760, -0,064 e 7,081, para a calibração e validação respectivamente. A espectrometria VIS-NIR é viável como ferramenta de avaliação de genótipos em programas do melhoramento de macaúba.
\end{abstract}

Palavras-chave: Acrocomia aculeata. Quantificação do óleo. Calibração de modeloVIS-NIR.

\footnotetext{
*Autor para correspondência

${ }^{1}$ Recebido para publicação em 24/09/2012; aprovado em 23/09/2014

Parte da Dissertação de Mestrado do primeiro autor apresentada...

${ }^{2}$ Departamento de Agronomia, Instituto de Investigação Agrária de Moçambique, Maputo, Moçambique, smatsimbe.mz@gmail.com

${ }^{3}$ Departamento de Fitotecnia, Universidade Federal de Viçosa, Viçosa, MG, Brasil, motoike@ufv.br

${ }^{4}$ Departamento de Engenharia Agrícola, Universidade Federal de Viçosa, Viçosa, MG, Brasil, facpinto@ufv.br

${ }_{5}^{5}$ Departamento de Engenharia Florestal, Universidade Federal de Viçosa, Viçosa, MG, Brasil, hleite@ufv.br

${ }^{6}$ Programa de Pós-Graduação em Ciência Florestal, Departamento de Engenharia Florestal, Universidade Federal de Viçosa, Viçosa, MG, Brasil, gustavomarcatti@gmail.com
} 


\section{INTRODUCTION}

The macaúba [Acrocomia aculeata (Jacq.) Lodd. Ex Mart.] is a rustic oilseed which, due to the high oil content of its fruit, has high productivity and great potential. Oil from the mesocarp, which is rich in oleic acid (COCININI, 2012; COIMBRA; JORGE, 2011), is of great demand in the food industry, and especially the energy industries because of its suitability for biodiesel production. Oil extracted from the endosperm is rich in lauric acid (BORA; ROCHA, 2004; COIMBRA; JORGE, 2011), and is therefore a valuable raw material in the cosmetic industry. Another application of economic importance is the use of its endocarp carbon in metallurgical and steelmaking operations.

Recently, studies aimed at the genetic improvement of the species have been set up at major research centres in Brazil. To assess the productive potential of different genotypes, qualitative and quantitative chemical analyses of the fruit of the macauba palm are required. However one of the difficulties faced by researchers is being able to access this information in the fruit due to the laborious and expensive processes of conventional methods of evaluation (QUAMPAH et al., 2012). For example, the evaluation of a single sample to determine the oil content using the standard method, Soxhlet, requires approximately 50 hours between prior preparation of the sample and the extraction itself, without taking into consideration that the solvent (n-hexane) used for extraction of the oil is toxic and polluting.

Accordingly, visible and near infrared (VIS-NIR) spectrometry is a tool for fast and efficient evaluation, which can be applied both to plant breeding and in industry. In several studies, the use of VIS-NIR spectrometry has been proposed in the development of models for the prediction of the oil content of various oilseeds: sunflower (PÉREZ-VICH et al., 1998), rapeseed (VELASCO et al., 1999a), Brassicaceae (VELASCO et al., 1999b), safflower (ELFADL et al., 2010; RUDOLPHI et al., 2012), Jatropha (VAKNIN et al., 2011) and cotton (QUAMPAH et al., 2012). However, to date there are no reports of its application on specific fruit fractions, such as palm mesocarp. The above studies have reported numerous benefits from spectrometric techniques, namely: speed, high precision, practicality and cost-effectiveness. Also the techniques allow for the assessment of more than one parameter in a single analysis, are non-destructive and do not require the use of chemical reagents or prior preparation of the samples (BAYE; BECKER, 2004; ROSSEL et al., 2005).

The aim of this work was to develop a model for predicting the oil content of the mesocarp of macauba fruit using VIS-NIR spectrometry.

\section{MATERIAL AND METHODS}

\section{Samples}

In the study, 840 fruits of the macauba were used, taken from various palm trees in natural populations in the towns of Acaiaca $\left(20^{\circ} 23^{\prime} 33^{\prime \prime} \mathrm{S}\right.$ and $43^{\circ} 07^{\prime} 31^{\prime \prime} \mathrm{W}$, at an altitude of $601 \mathrm{~m}$ ) and Piranga (20'41'46" S and 43'15'28' $\mathrm{W}$, at an altitude of $606 \mathrm{~m}$ ) in the state of Minas Gerais, Brazil. In each region, bunches were tagged at anthesis to monitor the development and maturation of the fruit. Ten bunches (one bunch per plant) were tagged in each population, giving a total of 20 bunches. Harvesting of the fruit started 314 days after anthesis, and was repeated at intervals ranging from 15 to 30 days, up to 495 days after anthesis. In total, nine harvests were carried out, with each harvest representing a maturation stage of the fruit. For each bunch six fruits were harvested, two for each position in the bunch: basal, median and apical. One sample unit consisted of two fruits per position per crop, totalling 420 samples. After harvesting, the samples were stored in a freezer at $-20{ }^{\circ} \mathrm{C}$ until measurement of the spectral data.

\section{Measurement of the spectral data and determination of the reference values}

Spectral data were measured with the FieldSpec ${ }^{\circledR}$ HandHeld $\quad 2^{\mathrm{TM}} \quad$ spectroradiometer (ANALYTICAL SPECTRAL DEVICES Inc, 2011), working in reflectance mode in the 325-1,075 nm wavelength band, at a sampling interval of $1.5 \mathrm{~nm}$ and accuracy of $\pm 0.1 \mathrm{~nm}$. A white reference plate with approximately $100 \%$ reflectance across the spectrum (ANALYTICAL SPECTRAL DEVICES Inc, 2011) was used as the reference standard, and the integration time was optimised for $1.09 \mathrm{~s}$ by maximizing measurement of the spectral signal, in order to avoid saturation and minimize the occurrence of noisy spectra. Before each measurement, a portion of the epicarp was removed from each fruit in order to expose the mesocarp to the optical probe of the spectroradiometer. Measurement of reflectance was carried out by placing the fruit in a suitable container, so as to minimise the occurrence of noise related to the scattering of light. After measurement, the reflectance spectra were processed using the ViewSpec Pro ${ }^{\mathrm{TM}}$ software to obtain the reflectance values used in adjustment of the VIS-NIR model, while the samples were again stored in the freezer at $-20{ }^{\circ} \mathrm{C}$ until determination of the reference values for oil content using the Soxhlet method.

To determine reference values, samples were thawed at room temperature and then pulped. The resulting mesocarp was cut into small pieces, which were dried in a ventilated oven for 48 hours at $65{ }^{\circ} \mathrm{C}$, then ground and finally placed into filter cartridges, at $\pm 5 \mathrm{~g}$ 
of sample per cartridge. Extraction of the oil and later determination of the reference values were carried out using the Soxhlet method, considered the standard method for quantification of oil in fatty products (AMERICAN OIL CHEMIST' SOCIETY, 1994). This method consists of a semi-continuous extraction in which the material to be extracted, generally fats and waxes, is more soluble in a hot solvent than at room temperature or when cold. The procedure includes steps of boiling followed by washing in order to obtain a residual extract from the sample (ANDERSON, 2004).

\section{Adjustment of the VIS-NIR model}

The model was adjusted using the 400-999 $\mathrm{nm}$ spectral band, due to the presence of significant noise in the 325-399 $\mathrm{nm}$ and 1,000-1,075 nm bands. Before adjusting the model, the spectral data were pre-treated using the technique of multiplicative signal correction (MSC) (BLANCO et al., 2001; JIANG et al., 2007; MOGHIMI et al., 2010). MSC is a treatment based on the separation of multiplicative and additive effects of light dispersion in NIR measurements, minimising spectral variations that are not the result of analyte concentration (BLANCO et al., 2001).

The VIS-NIR model to predict the oil content in the mesocarp was adjusted by correlating the spectral data with the reference values, using partial least squares regression (PLSR) (FEUDALE et al., 2002; LI et al., 2002; LIU et al., 2009; MEVIK et al., 2004) employing the R software (R DEVELOPMENT CORE TEAM, 2012). Two thirds of the samples were used for the calibration set and for cross validation, and the rest for the external validation set. To avoid overfitting the model, the optimal number of latent variables (LVs) was determined, considering the minimum value for the root mean square error of cross validation (RMSECV) (BALBIN; SMIRNOV, 2011; MEVIK; CEDERKVIST, 2004; YENIAY; GÖTKAS, 2002). Cross-validation was used only to define the optimal number of latent variables.

\section{Statistical analysis}

To evaluate the predictive capacity of the adjusted models, different statistical parameters were used:

a) The accuracy of correlation (bias) between the reference method and the developed model, which represents the systematic error between the predicted values and the measured values, where values close to zero indicate high accuracy of the model (ELFADL et al., 2010). This parameter is given by estimator 1 .

$$
\text { bias }=\frac{\sum_{j=1}^{n}\left(y_{j}-\hat{y}_{j}\right)}{n}
$$

where: $y_{j}=$ value measured by the Soxhlet method for the sample $\mathrm{j}, \hat{y}_{j}=$ the value predicted by the VIS-NIR model for the sample $\mathrm{j}$ and $n=$ number of samples.

b) The root mean square error (RMSE) between the reference method and the developed model, represented by RMSEC for the calibration or estimation set and RMSEP for the prediction or external validation set. The RMSE is given by estimator 2 .

$R M S E=\sqrt{\frac{\sum_{j=1}^{n}\left(y_{j}-\hat{y}_{j}\right)^{2}}{n}}$

c) The relative percentage error (ER) between the reference method and the developed model, given by estimator 3 .

$E R(\%)=\frac{\left(y-\hat{y}_{j}\right)}{y_{j}} \times 100$

d) The coefficient of determination $\left(R^{2}\right)$ between the reference method and the developed model, which was estimated for all sets: calibration $\left(\mathrm{R}^{2}\right)$, crossvalidation $\left(\mathrm{R}_{\mathrm{cv}}^{2}\right)$ and prediction or external validation $\left(\mathrm{R}_{\mathrm{p}}^{2}\right)$, employing estimator 4 .

$$
R^{2}=\frac{\left[\sum_{j=1}^{n}\left(\hat{y}_{j}-\bar{y}\right)\left(y_{j}-\bar{y}\right)\right]^{2}}{\sum_{j=1}^{n}\left(\hat{y}_{j}-\bar{y}\right)^{2} \sum_{j=1}^{n}\left(y_{j}-\bar{y}\right)^{2}}
$$

where: $\bar{y}=$ mean measured value and $\bar{y}=$ mean predicted value.

\section{RESULTS AND DISCUSSION}

\section{Variability of the macauba samples}

In Table 1 can be seen a summary of the analysis of variability in the samples used in adjusting the model. According to the results, the variation in oil content seen between the samples, from 0.30 to $55.67 \%$ for the calibration set and 0.44 to $56.03 \%$ for the validation set, suggests that the variability between samples was suitable for analysis.

\section{Effect of pre-treatment of the spectral data}

Two models were tested, one using the original spectral data and the other data pre-treated by MSC. 
Table 1 - Summary of the analysis of variability in the samples of macauba used for the calibration and validation sets

\begin{tabular}{lc}
\hline \multicolumn{1}{c}{ Statistical parameter } & Oil content $(\%)$ \\
\hline Calibration set (estimate) & 55.67 \\
Maximum & 28.82 \\
Mean & 0.30 \\
Minimum & 14.07 \\
Deviation & 48.82 \\
CV & \\
\hline Validation set (prediction) & 56.03 \\
Maximum & 27.88 \\
Mean & 0.44 \\
Minimum & 14.94 \\
Deviation & 53.59 \\
CV &
\end{tabular}

According to the results in Table 2, use of the original spectral data required $10 \mathrm{LVs}$ to adjust the VIS-NIR model. While pre-treatment by MSC allowed adjustment of the VIS-NIR model using fewer VLs (nine), and with better predictive capability, as evidenced by the relatively low values for RMSEC (5.917) and RMSEP (7.081) and the relatively high values for $\mathrm{R}^{2}{ }_{\mathrm{c}}(0.8223)$ and $\mathrm{R}_{\mathrm{p}}^{2}(0.7760)$. In spectrometry, physical effects such as light and/or the state of the sample, affect the variability of the samples, contributing to the use of a large number of samples in the calibration set and resulting in complex models of low predictive capability (BLANCO et al., 2001). The use of pre-treatments such as MSC enables the correction of spectral variations that are not induced by analyte concentration (BLANCO et al., 2001; MOGHIMI et al., 2010) and consequently improvements in the capability of the models.

Due to the results shown in Table 2, adjustment of the VIS-NIR model was performed using spectra pretreated by MSC.

\section{Determining the number of latent variables to adjust the model}

Figure 1 demonstrates that nine LVs were needed to adjust the best VIS-NIR model. The use of more than nine LVs leads to an over-adjusted model, characterised by a divergence in the trend of the RMSE, decreasing for calibration and decreasing for cross-validation (Figure 1a), whereas $\mathrm{R}^{2}$ increased for the calibration set and decreased for cross-validation (Figure $1 \mathrm{~b}$ ). This assumes that the use of many LVs, more than nine, increases the error and lowers the predictive robustness of the VIS-NIR model. Quampah et al. (2012), Liu et al. (2009), Sivakesava and Irudayaraj (2002) and Swierenga et al. (1999) consider that over-adjusted models can be avoided by selecting the optimal number of LVs using the minimum RMSECV, with a relatively high $\mathrm{R}^{2}$.

\section{Calibration and external validation}

Table 3 summarises the statistics for the calibration set, which recorded values for the RMSEC of 5.917, bias $_{c}$ of $-9,2$ and -15 , and of 0.8223 for $\mathrm{R}_{c}^{2}$. These results suggest the good predictive ability of the model. Quampah et al. (2012), Moghimi et al. (2010) and Liu et al. (2009) consider that the best model presents high values for $\mathrm{R}^{2}$ and low values for RMSEC and RMSEP.

Also in Table 3 are presented the statistical results of the external validation, which were consistent with the results seen for the calibration set, recording values for $\mathrm{R}^{2}$ of 0.7760 and RMSEP of 7.081. The value of bias $(-0.064)$ remained close to zero, indicating that the accuracy seen for the calibration set was also maintained for the prediction set (external validation). Another relevant fact seen was the high consistency $(83.56 \%)$ of the model, given by the ratio of RMSEC to RMSEP, showing this was optimized by including the best number of LVs. According to Roggo et al. (2003), quantitative models are considered to be of high accuracy when they present low values for bias and RMSE. While Elfadl et al. (2010) consider that for the model to be thought of as consistent the RMSEC to RMSEP ratio should be close to one.

Table 2 - Summary of the effect of pre-treatment on the spectral data

\begin{tabular}{lccccc}
\hline Pre-treatment & LVs & RMSEC & RMSEP & $\mathrm{R}_{\mathrm{c}}^{2}$ & $\mathrm{R}_{\mathrm{p}}^{2}$ \\
\hline Original spectra & 10 & 6.592 & 7.214 & 0.7796 & 0.7651 \\
MSC spectra & 9 & 5.917 & 7.081 & 0.8223 & 0.7760 \\
\hline
\end{tabular}

Where: $\mathrm{MSC}=$ multiplicative signal correction, $\mathrm{LVs}=$ latent variables, RMSE = root mean square error (RMSEC for calibration and RMSEP for prediction) and $\mathrm{R}^{2}=$ coefficient of determination $\left(\mathrm{R}_{\mathrm{c}}^{2}\right.$ for calibration and $\mathrm{R}_{\mathrm{p}}^{2}$ for prediction) 
Figure 1 - Graphical representation of the determination of the optimal number of LVs used to adjust the model, employing the RMSE (a) and $\mathrm{R}^{2}$ (b). Where: $C=$ calibration, $C V=$ cross-validation, $V C$-adj $=$ adjusted cross-validation, $E V=$ external validation and $L V s=$ latent variables
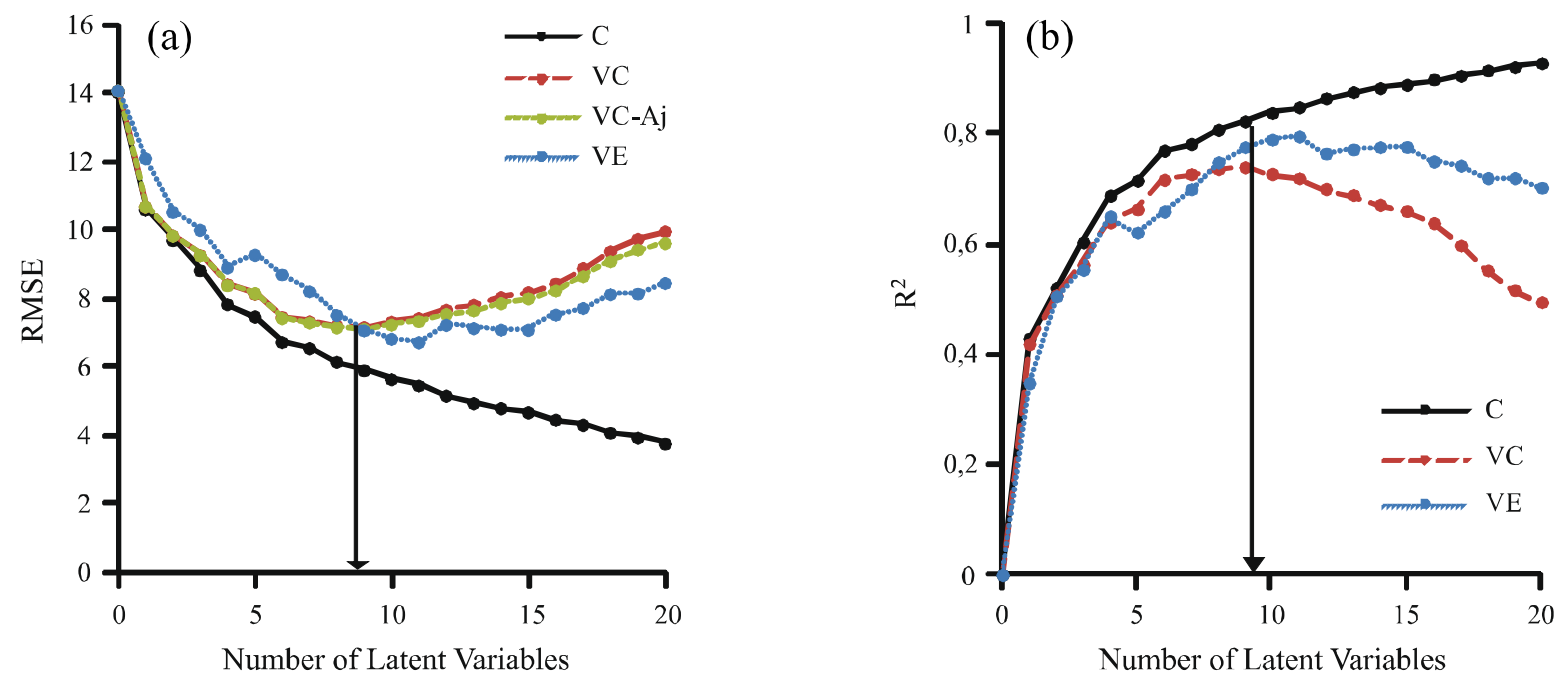

Table 3 - Summary of the statistics for calibration and external validation of the model for predicting the mesocarp oil content of macauba fruit

\begin{tabular}{cccccccc}
\hline \multirow{3}{*}{ Model } & \multirow{2}{*}{ LV } & \multicolumn{4}{c}{ Modelled for oil contente (\%) } \\
\cline { 3 - 8 } & & \multicolumn{3}{c}{ Calibration (estimation) } & \multicolumn{2}{c}{ External validation (prediction) } \\
\cline { 3 - 8 } & & $\mathrm{R}^{2}{ }_{\mathrm{c}}$ & RMSEC & biasc & $\mathrm{R}_{\mathrm{p}}^{2}$ & RMSEP & biasp \\
\hline VIS-NIR & 9 & 0.8223 & 5.917 & $-9.2 \mathrm{e}-15$ & 0.7760 & 7.081 & -0.064 \\
\hline
\end{tabular}

Where: $L V S=$ latent variables, $R M S E=$ root mean square error $(R M S E C$ for calibration and $R M S E P$ for prediction $), R^{2}=$ coefficient of determination $\left(R_{c}^{2}\right.$ for calibration and $R_{p}^{2}$ for prediction) and bias = accuracy of correlation (bias for calibration and bias $_{p}$ for prediction)

Presented in Figure 2 is a graphical visualisation of the correlation between the Soxhlet method and the VISNIR model. It can be seen that there is a linear correlation between the values predicted by the VIS-NIR model with the reference values, describing the same trend of a $45^{\circ}$ line as the calibration set (Figure 2a). For the external validation, a significant correlation between the values predicted by the VIS-NIR model with the values obtained by the Soxhlet method (Figure $2 \mathrm{~b}$ ) was also observed.

The histograms shown in Figure 3 display the residual distribution for the calibration and external validation sets. The residuals were distributed between values of $\pm 100 \%$ in the sets, showing greater confinement between values of $\pm 5 \%$ and centralised on $0 \%$, following a normal distribution.

The verified results were generally promising, indicating that VIS-NIR spectrometry has the potential to be applied as an alternative method in quantifying mesocarp oil in macauba fruit.
The VIS-NIR model developed in this work recorded a robustness of $82.23 \%$ for calibration and $77.60 \%$ for prediction in the $400-999 \mathrm{~nm}$ spectral band. In practice, this result is highly relevant, considering that this band coincides with the spectral coverage of most portable spectroradiometers. The practical advantage of using this band is in the possibility of conducting analyses both in the laboratory and directly in the field.

The work carried out on other oilseeds, aiming at the calibration of models for prediction of the oil content by spectrometry, and referred to here, have only reported results in the near infrared spectral region. Baye and Becker (2004) studied the potential of NIRS to access the profile of fatty acids and the oil and protein content of seeds from the Vernonia galamensis germplasm, finding an $\mathrm{R}^{2}$ of 0.71 for the prediction model of oil content. Spectral coverage was in the 1,100-2,500 nm wavelength band. Elfadl et al. (2010) with safflower $\left(\mathrm{R}^{2}=0.90\right)$ and Quampah et al. 
Figure 2 - Correlation between the estimated and observed values for the two methods: calibration (a) and external validation (b). Where $R=$ linear correlation
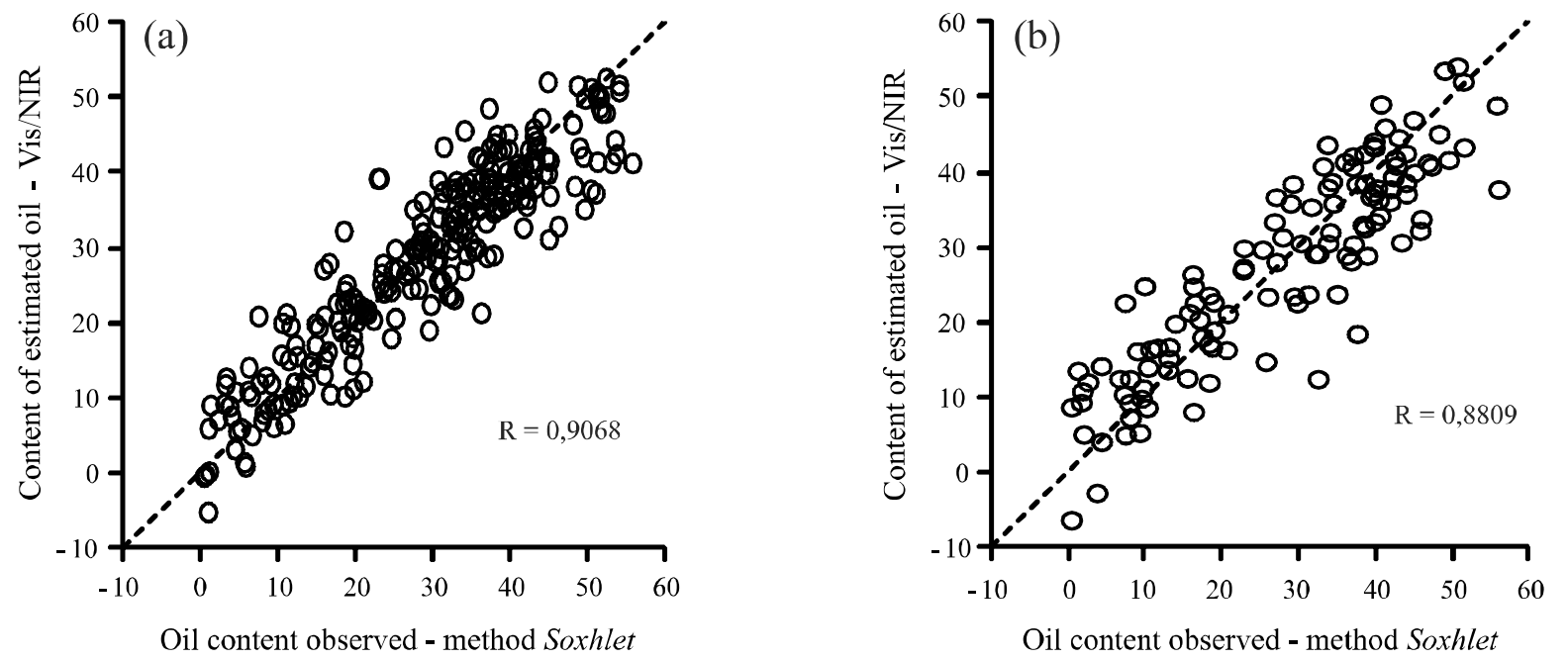

Figure 3 - Histograms of the residuals: calibration (a) and external validation (b)
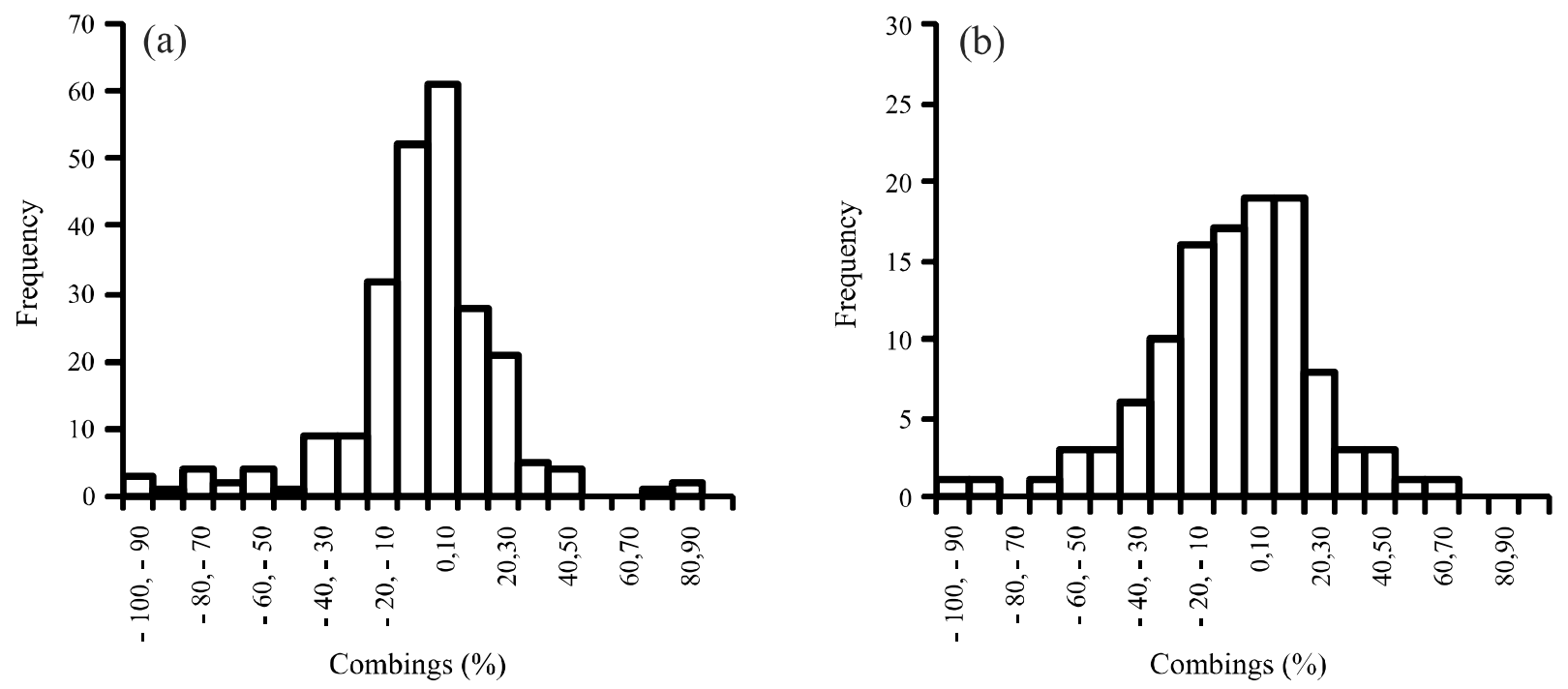

(2012) with cotton $\left(\mathrm{R}^{2}=0.99\right)$ were other authors who have reported interesting results working in the spectral band of wavelengths above $1,100 \mathrm{~nm}$.

Velasco et al. (1999b), in similar work with seeds from the Brassicaceae germplasm, developed a model for the prediction of oil content having an $\mathrm{R}^{2}$ equal to 0.97. However, even though measuring reflectance in the spectral band between 400 and 2,500 $\mathrm{nm}$, the models were calibrated using spectral information from the band between 1,100 and 2,500 nm; spectral information from wavelengths below $1,100 \mathrm{~nm}$ being

irrelevant for a robust model. Jiang et al. (2007) worked with wavelengths between 780-2,500 nm, however in order to characterise maize in terms of oil content, only the spectral bands from 1,114 to $1,836 \mathrm{~nm}$ and between 2,171 and 2,357 $\mathrm{nm}$ were relevant in obtaining robust models $\left(\mathrm{R}^{2}=0.94\right.$ to 0.95$)$. For Velasco et al. (1999a) with rapeseed, although also working with the 4002,500 $\mathrm{nm}$ spectral band, only the bands between 1,100 and 1,460 $\mathrm{nm}$ and between 1,560 and 2,500 $\mathrm{nm}$ were relevant, obtaining models with an $\mathrm{R}^{2}$ of 0.92 . PérezVich et al. (1998), similar to the other authors, found 
that only the spectral band between 1,100 and 2,500 nm was relevant when obtaining robust models to access the oil content of sunflower seeds. However, they also reported differences in the robustness of the models when using the NIRS spectra of intact seeds $\left(\mathrm{R}^{2}\right.$ from 0.76 to 0.85$)$, milled seeds ( $\mathrm{R}^{2}$ from 0.92 to 0.98$)$ and husked seeds ( $\mathrm{R}^{2}$ from 0,90 to 0.97$)$.

With regard to the above it is evident that, along with their chemical attributes, both the physical characteristics of the samples and the spectral region used are also of great relevance in the calibration of predictive models, influencing their robustness.

\section{CONCLUSION}

VIS-NIR spectroscopy is a robust and practical alternative when quantifying the oil content of the mesocarp of macauba palm fruit. Its use would be beneficial in terms of time and cost savings, in addition to the environmental advantages, since it would significantly reduce the number of analyses needed by the standard, Soxhlet method. It is also a viable tool for the evaluation of genotypes in breeding programs for the macauba palm.

\section{ACKNOWLEDGEMENT}

The authors acknowledge the support of the institutions CNPq e FAPEMIG.

\section{REFERENCES}

AMERICAN OIL CHEMIST' SOCIETY. Official methods and recommended practices of the American Oil Chemist's Society. Fourth edition. Washington: American Oil Chemist's Society Press, 1994. Cd 3d-63.

ANALYTICAL SPECTRAL DEVICES Inc. FieldSpec ${ }^{\circledR}$ HandHeld $2^{\text {TM }}$ Spectroradiometer user manual. ASD Document 600860 Rev. D, 92 p. 2011. Disponível em: <www.asdi.com>. Acesso em: 10 set. 2011.

BALBIN, R. M.; SMIRNOV, S. V. Variable selection in near infrared spectroscopy: Benchmarking of feature selection methods on biodiesel data. Analytica Chimica Acta, v. 692, n. $1 / 2$, p. $63-72,2011$

BAYE, T.; BECKER, H. C. Analyzing seed weight, fatty acid composition, oil, and protein contents in Vernonia galamensis germoplasma by near infrared reflectance spectroscopy. Journal of the American Oil Chemist's Society, v. 81, n. 7, p. 641-645, 2004.
BLANCO, M. et al. Orthogonal signal correction in near infrared calibration. Analytica Chimica Acta, v. 434, n. 1, p. 125-132, 2001.

BORA, P. S.; ROCHA, R. V. M. Macaíba palm: fatty and amino acids composition of fruits. Ciência Tecnologia \& Alimentos, v. 4 , n. 3 , p. $158-162,2004$

COCININI, G. Caracterização de frutos e óleo da polpa de macaúba dos biomas do cerrado e pantanal do estado de Mato Grosso do Sul, Brasil. 2012. 128 f. Dissertação (Mestrado em Biotecnologia) - Universidade Católica Dom Bosco, Campo Grande, 2012.

COIMBRA, M. C.; JORGE, N. Characterization of the pulp and kernel oils from Syagrusoleracea, Syagrusromanzoffiana, and Acrocomia aculeata. Journal of Food Science, v. 76, n. 8, p. 1151-1161, 2011

ELFADL, E. et al. Development of near infrared reflectance spectroscopy (NIRS) calibration model for estimation of oil content in a worldwide Safflower germoplasm collection. International Journal of Plant Production, v. 4, n. 4, p. 259$270,2010$.

FEUDALE, R. N. et al. Transfer of multivariate calibration models: a review. Chemometrics and Intelligent Laboratory Systems, v. 62, n. 2, p. 181-192, 2002.

JIANG, H. Y. et al. Analysis of protein, starch and oil content of single intact kernels by near infrared reflectance spectroscopy (NIRS) in Maize (Zea mays L.). Plant Breeding, v. 126, n. 5, p. 492-497, 2007.

LI, B. et al. Model selection for partial least squares regression. Chemometrics and Intelligent Laboratory Systems, v. 64, n. 1, p. 79-89, 2002.

LIU, F. et al. Variable selection in visible/near infrared spectra for linear and nonlinear calibrations: A case study to determine soluble solids content of beer. Analytica Chimica Acta, v. 634, n. 1, p. 45-52, 2009

MEVIK, BJORN-HELGE; CEDERKVIST, H.R. Mean Squared Error of Prediction (MSEP) Estimates for Principal Component Regression (PCR) and Partial Least Squares Regression (PLSR). Journal of Chemometrics, v. 18, n. 09, p. 422-429, 2004.

MEVIK, BJORN-HELGE et al. Ensemble methods and partial least squares regression. Journal of Chemometrics, v. 18 n. 11, p. 498-507, 2004

MOGHIMI, A. et al. Vis/NIR spectroscopy and chemometrics for the prediction of soluble solids content and acidity $(\mathrm{pH})$ of kiwifruit. Biosystems Engineering, v. 106, n. 3, p. 295-302, 2010.

PÉREZ-VICH, B. et al. Determination of seed oil content and fatty acid composition in Sunflower through the analysis of intact seeds, husked seeds, meal and oil by near infrared reflectance spectroscopy. Journal of the American Oil Chemist's Society, v. 75 , n. 5 , p. $547-555,1998$.

QUAMPAH, A. et al. Estimation of oil content and fatty acid composition in Cotton seed kernel powder using near 
infrared reflectance spectroscopy. Journal of the American Oil Chemist's Society, v. 89, n. 4, p. 567-575, 2012.

R DEVELOPMENT CORE TEAM. R: A language and environment for statistical computing. R Foundation for Statistical Computing, 2012. Disponível em: <www.Rproject.org> Acesso em: 10 set. 2012.

ROGGO, Y. et al. Statistical tests for comparison of quantitative and qualitative models developed with near infrared spectral data. Journal of Molecular Structure, v. 654, n. 1/3, p. 253262, 2003.

ROSSEL, R. A. V. et al. Visible, near infrared, mid infrared or combined diffuse reflectance spectroscopy for simultaneous assessment of various soils proprieties. Geoderma, v. 131, n. 1/2, p. 59-75, 2005.

RUDOLPHI, S. et al. Improved estimation of oil linoleic and oleic acid and seed hull fractions in Safflower by NIRS. Journal of the American Oil Chemist's Society, v. 89, n. 3, p. 363-369, 2012.

SIVAKESAVA, S.; IRUDAYARAJ, J. Rapid determination of tetracycline in milk by FT-MIR and FT-NIR spectroscopy. Journal Dairy Science, v. 85, n. 3, p. 487-493, 2002.
ANDERSON, S. Soxtec: Its principles and applications. AOCS Press, 2004. Chapter 2, 14 p.

SWIERENGA, H. et al. Strategy for constructing robust multivariate calibration models. Chemometrics and Intelligent Laboratory Systems, v. 49, n. 1, p. 1-17, 1999.

VAKNIN, Y. et al. Predicting Jatropha curcas seed-oil content, oil composition and protein content using near infrared spectroscopy - a quick and nondestructive method. Industrial Crops and Products, v. 34, n. 1, p. 1029-1034, 2011.

VELASCO, L. et al. Estimation of seed weight, oil content and fatty acid composition in intact single seeds of rapeseed (Brassica napus L.) by near infrared reflectance spectroscopy. Euphytica, v. 106, n. 1, p. 79-85, 1999a.

VELASCO, L. et al. Development of calibration equations to predict oil content and fatty acid composition in Brassicaceae germoplasm by near infrared reflectance spectroscopy. Journal of the American Oil Chemist's Society, v. 76, n. 1, p. 25-30, 1999b.

YENIAY, Ö.; GÖKTAS, A. A comparison of partial least squares regression with other prediction methods. Hacettepe Journal of Mathematics and Statistics, v. 31, p. 99-111, 2002. 